\title{
Rompendo silêncios: narrativas afrodescendentes no Brasil e na Alemanha
}

\author{
Breaking the silence: afrodescendant narratives in Brazil and in German
}

Jessica Oliveira de Jesus ${ }^{1}$

DOI: $10.28998 / 2317-9945.2019 n 63 p 247-259$

\section{Resumo}

O presente texto faz uma breve análise comparativa entre produçoes literárias negras em língua alemã e em língua portuguesa do Brasil. O foco da análise é o afronte à estratégia colonial do silenciamento, imposto ao povo negro em diáspora, operado na obra da poeta e ativista afro-alemã May Ayim e da romancista afrobrasileira Ana Maria Gonçalves. Trataremos da literatura da diáspora africana como ferramenta que "estilhaça a máscara do silêncio" (EVARISTO, 2017), tanto na obra Um defeito de cor (2006), de Gonçalves, como na poesia afro-alemã de May Ayim e de sua tradução no Brasil, traçando paralelos e diálogos entre a literatura negra brasileira e a negra alemã.

Palavras-chave: Literatura Negra Brasileira. Literatura Negra Alemã. Literatura Afrodiaspórica. Ana Maria Gonçalves. May Ayim

\begin{abstract}
The present text is a brief comparative analysis between Black literary productions in German and Brazilian Portuguese. The focus of the analysis is the defiance of the colonial strategy of silencing, inflicted on Black people in the diaspora, which can be seen in the work of the Afro-German poet and activist May Ayim and of the Afro-Brazilian novelist Ana Maria Gonçalves. We will deal with African Diaspora Literature as a tool that "shatters the mask of silence" (EVARISTO, 2017), both in Goncalves's Um defeito de cor (2006), and in Ayim's Afro-German poetry and its translation into Brazilian Portuguese, drawing parallels and dialogues between Black Brazilian literature and the Black German Literature.
\end{abstract}

Keywords: Black Brazilian Literature. Black German Literature. Afrodiasporic Literature. Ana Maria Gonçalves. May Ayim

Recebido em: 09/07/2018.

Aceito em: 18/10/2018.

\footnotetext{
${ }^{1}$ Doutorando em Literatura e Cultura na Universidade Federal da Bahia. Mestra em Estudos da Tradução pela Universidade Federal de Santa Catarina.
} 
As reflexões que se seguem traçam, através da literatura negra em diáspora no Brasil e Alemanha, processos de quebra dos silenciamentos impostos ao povo negro em diáspora, bem como acerca de nossas histórias. Tais processos são multíplices, pois se dão por um lado, através das/os escritoras/es negras/os, e, por outro lado, através de suas personagens e eu-líricos negras e negros, que nessa literatura, diferentemente do que acontece no cânone, são retratadas em primeira pessoa e/ou "segue[m] sua trajetória de identidade e de consolidação gradativa de uma alteridade no ponto de emanação do discurso" (CUTI, 2010, p. 33). Essa elaboração também tem efeitos nos/as leitores/as, principalmente em leitoras negras, já que este público raramente se vê retratado nas literaturas nacionais enquanto pessoas humanas com subjetividade, história, etc.

Além desta reflexão, o texto busca também contribuir para o mapeamento de trabalhos teóricos acerca da literatura negra, citando a dissertação de mestrado intitulada "May Ayim e a tradução de poesia afrodiaspórica de língua alemã", defendida recentemente no Programa de Pós-graduação em Estudos da Tradução da UFSC.

O romance Um defeito de cor (2006), da escritora afro-brasileira Ana Maria Gonçalves, se enquadra nas características supracitadas e é tomado aqui como ponto de partida e chave de leitura para a análise proposta. Neste livro, história e ficção se mesclam de maneiras elaboradas, resultando em grande verossimilhança e logrando que o/a leitor/a revisite e olhe, desde outras perspectivas, períodos decisivos da história brasileira. $\mathrm{O}$ romance épico de Gonçalves bota o dedo na "ferida colonial" trazendo em primeiro plano as experiências de Kehinde, uma senhora de 89 anos e ex-escravizada que, em tom memorialístico, conta ao seu filho sua história de vida desde o período posterior ao seu sequestro por traficantes de humanos para a escravização no Brasil, quando tinha aproximadamente seis anos. "Eu nasci em Savalu, reino de Daomé, África, no ano de um mil oitocentos e dez" (GONÇALVES, 2006, p. 19). Seu relato passa pela escravização na ilha de Itaparica e na cidade de Salvador, por suas andanças pelo Maranhão - onde encontra Na Agontimé ${ }^{2}$-, pela busca por seu filho no Rio de Janeiro, Santos, São Paulo, Campinas, pelo seu retorno ao continente africano, onde se torna empresária bem-sucedida na área de construção civil, e por fim, pela sua volta ao Brasil. Marilene Weinhardt (2009) lê o romance sob a perspectiva da "ficção histórica", justamente pelo fato de que nele aparecerem ficcionalizadas diversas figuras e eventos que re-conhecemos dos livros de história. Nesse caso específico, tratam-se de figuras negras, escravizadas, forras, organizadores/as de revoltas, como a dos Malês, por exemplo. Um defeito de cor configura-se como documento que resgata personagens, eventos e pontos de vista sobre a história e literatura, enriquecendo e enegrecendo a memória cultural de afrodescendentes, pois essa parte da história foi, e ainda é, mal documentada e não nos é contada. Para Linda Hutcheon (1991):

A metaficção historiográfica [...] ressalta a natureza discursiva de todas as referências - literárias e historiográficas. O referente é sempre já inserido nos discursos de nossa cultura. Isso não é motivo de desespero; é o principal vínculo do texto com o "mundo", um vínculo que reconhece sua identidade como construto, e não o simulacro de um exterior 'real'. Mais uma vez, isso não nega que o passado 'real' tenha existido; apenas condiciona nossa forma de conhecer esse passado. Só podemos

\footnotetext{
${ }^{2}$ Ná Agontimé, rainha do reino do Daomé, atual República do Benim, foi sequestrada e levada ao Maranhão e sob o nome de Maria Jesuína comprou sua alforria e organizou o culto aos voduns, ancestrais divinizados da família real do Daomé, fundando por volta de 1840 a Casa das Minas no Maranhão. Fonte: <http://www.afrika.org.br/publicacoes/somos-todas-rainha-1ed.pdf>. Acesso em: 19 out. 2018.
} 
conhecê-lo por meio de seus vestígios, de suas relíquias (HUTCHEON, 1991, p. 158).

Deste modo, o romance de Gonçalves, ao narrar desde a perspectiva de uma exescravizada episódios como o sequestro em Uidá, a viagem no navio negreiro, a escravização, o processo de independência do Brasil, revoltas de escravizados/as, a presença e influência do povo malê, africanos muçulmanos escravizados e literalmente "banidos da história" (GONÇALVES, 2006, p. 11), etc., reúne vestígios da história, funcionando como exercício político que proporciona a quem o lê acesso a outras histórias, questionando a História (única) oficial, que por sua vez, não passa de um discurso, montado e articulado de acordo com os interesses de quem a narra. Para Duarte (2011, p. 5), a "metaficção historiográfica" em Gonçalves é o espaço "onde emergem as vozes de uma memória afro-brasileira colocada nos antípodas da história oficial, que tensionam o discurso do romance rumo ao acoplamento e co-habitação de versões díspares [da história]". Em mais de um momento da narrativa percebemos fatos da história oficial pelo olhar da protagonista Kehinde, que os formula a partir de seu ponto de vista negro. Para Kehinde e para os seus, a história oficial pouco importa(va) por não dizer respeito a eles e elas. Há, ao longo do romance, uma recusa de focar-se nas grandes figuras: "[...] são coisas que não nos interessam, isso dos reis já está por aí nos livros dos brancos [...]" (GONÇALVES, 2006, p. 622). Em comentários como este, o foco narrativo canônico/oficial é deslocado, e a história, outrora "de fundo", isto é, dos/as escravizados/as passa ao primeiro plano, ganha voz, corpo, complexidade e sentido.

Para Weinhardt (2009, p. 111) "É a conjugação deste potencial individual com as intervenções do acaso e a incorporação de circunstâncias históricas que justificam uma existência tão plena de peripécias sem resvalar para a inverossimilhança". Para além de toda a riqueza documental e complexidade narrativa de $U m$ defeito de cor, o que nos interessa aqui é sua importância e efeitos desde um ponto de vista da história afrodescendente no Brasil, já que a narrativa recupera tantos dados da memória afrodescendente, rompendo silêncios e lacunas históricas. Gonçalves (2016) afirma em entrevista que "escrever o livro foi a busca das minhas raízes negras, do entendimento de uma história do negro no Brasil, que me foi negada". O romance também supre, de um ponto de vista literário, uma demanda traçando uma continuidade - uma espécie de genealogia da literatura negro-brasileira - que nos remonta à figura de um dos primeiros escritores e poetas afrodescendentes reconhecidos no Brasil: Luiz Gama, figura histórica, escritor, poeta, advogado, jornalista abolicionista e ex-escravizado, nascido em Salvador em 1830 e falecido em São Paulo no ano de 1882, e que é na narrativa de Gonçalves rememorado e ficcionalizado na figura de Luis, filho vendido como escravo pelo pai em Salvador para pagar dívidas de jogo, e levado a São Paulo, assim como fora a própria figura histórica Luiz Gama. O advogado e escritor comprometido intensamente com a abolição da escravatura e símbolo para o movimento negro ficcionalizara, por sua vez, a figura histórica Luiza Mahin, africana escravizada no Brasil e envolvida nas principais revoltas de escravizados no estado da Bahia. Em carta para o amigo Lúcio de Mendonça, Gama escreve:

Sou filho natural de negra africana, livre, da nação nagô, de nome Luíza Mahin, pagã, que sempre recusou o batismo e a doutrina cristã. Minha mãe era baixa, magra, bonita, a cor de um preto retinto sem lustro, os dentes eram alvíssimos, como a neve. Altiva, generosa, sofrida e vingativa. Era quitandeira e laboriosa (MENNUCCI, 1938, p. 20).

Apesar de não haver documentos "oficiais" que comprovem a existência de Mahin, tampouco de seu envolvimento na Revolta dos Malês em Salvador (1835) ou na Sabinada 
(1837-38), a personagem vive na memória afrodescendente como símbolo da luta antiescravista e da articulação política de mulheres negras. Os rastros que remontam às personagens históricas ficcionalizadas no romance aparecem já no prólogo:

[...] esta pode não ser uma simples história, pode não ser a história de uma anônima, mas sim de uma escrava muito especial, alguém de cuja existência não se tem confirmação, pelo menos até o momento em que escrevo esta introdução. Especula-se que ela pode ser apenas uma lenda, inventada pela necessidade que os escravos tinham de acreditar em heróis, ou, no caso, em heroínas, que apareciam para salvá-los da condição desumana em que viviam. Ou então uma lenda inventada por um filho que tinha lembranças da mãe apenas até os sete anos, idade em que pais e mães são grandes heróis para seus filhos. Ainda mais quando observados por mentes espertas e criativas, como era o caso deste filho do qual estou falando, que nasceu livre, foi vendido ilegalmente como escravo, e mais tarde se tornou um dos principais poetas românticos brasileiros, [...] e um dos mais notáveis defensores dos escravos e da abolição da escravatura. Um homem inteligente e batalhador que, tendo nascido de uma negra e de um fidalgo português que nunca o reconheceu como filho, conseguiu se tornar advogado e passou a vida defendendo aqueles que não tiveram a sorte ou as oportunidades que ele tão bem soube aproveitar. O que você vai ler agora talvez seja a história da mãe deste homem respeitado e admirado pelas maiores inteligências de sua época. [...] Mas também pode não ser. E é bom que a dúvida prevaleça até que, pelo estudo do manuscrito, todas as possibilidades sejam descartadas ou confirmadas [...]. Torço para que seja verdade, para que seja ela própria a pessoa que viveu e relatou quase tudo o que você vai ler nesse livro. Coisas da Bahia, nas quais acredita quem quiser... (GONÇALVES, 2006, p. 16-17).

De acordo com Dalton Junior (2011, p. 5) a prática de simular editar um manuscrito era bastante comum no século XVIII em narrativas históricas literárias e parece muito coerente para o propósito de Gonçalves, que é desvelar a manipulação histórica, bem como visibilizar discursos e vozes de africanos/as e afrodescendentes. Ainda, segundo Danton Junior, esta prática aproxima o romance de Gonçalves a obras como "Don Quixote de la Mancha", de Miguel de Cervantes, que afirma que o autor de seu texto é Cide Hamere Benegeli, historiador árabe.

Há no final da narrativa uma bibliografia, outra característica que foge ao gênero romance: "Esta é uma obra que mistura ficção e realidade. Para informações mais exatas e completas sobre temas abordados, sugiro as seguintes leituras" (GONÇALVES, 2006, p. 949). E, apesar de também haver no prólogo declarações como: "Se eu me apropriasse da história, provavelmente a autoria nunca seria contestada, pois ninguém até então sabia da existência dos manuscritos (...)", o que a autora logra com tais afirmações é explicitar, não por um acaso no prólogo-pacto, que tem um projeto, uma conexão e continuidade com a história do povo negro no Brasil. De fato, Gonçalves, uma afro-brasileira é quem assina o livro e, de fato, a história é dela e, na realidade, não conhecemos tais personagens, já que, como temos discutido, a história "oficial" e a literatura silenciam e omitem a existência de figuras como Licutan, Luíza Mahin, Luíz Gama. A autora, justamente, alerta para a falta de material histórico sobre a história e literatura negras no Brasil e parece incitar pesquisas mais aprofundadas nestes campos. Partindo deste viés, a obra de Gonçalves nos refresca a memória acerca da história de insubmissão, das diferenças entre os/as escravizados/as, sobre estratégias comunitárias e rebelião negra. Assim, Kehinde, ou o "avatar ficcional de 
Mahin” (DUARTE, 2011, p. 7) passa a habitar e enriquece a memória histórico-cultural afrodescendente, pois sua história pode ter sido tanto a de Mahin quanto a de milhares de outras africanas sequestradas e escravizadas no Brasil. As ações praticadas, portanto, por/contra Kehinde servem de representação fictícia dos atos que foram realizados/sofridos por negras/os cativas/os reais no Brasil colonial, reconstruindo histórias não contadas. Para Weinhardt (2009):

Kehinde não é heroína de romance porque é negra escrava (sic). Kehinde é [...] escrava (sic) submetida a desmandos de diferentes ordens pelos donos, é revolucionária aprisionada e fugitiva, é amante abandonada, é forra ameaçada de expulsão por não ter lugar na sociedade, é mãe em busca do filho roubado, é mulher que percebe o companheiro distanciarse por ser ela capaz de iniciativa própria no mundo comercial, mas não é protagonista por nada disso, e sim porque empreende o relato dessas experiências (WEINHARDT, 2009, p. 114-115, grifo meu).

A importância de narrar a própria história é crucial na literatura da diáspora negra, pois ao fazê-lo o sujeito negro inverte relações de poder reproduzidas na literatura por séculos, isto é, passa a ser sujeito e não mais objeto e traz consigo a voz negra silenciada e/ou não escutada por tantos séculos. Este gesto é também observado na poesia da afroalemã May Ayim (Hamburgo, 1960 - Berlin, 1996). Filha de um estudante de medicina ganês e de uma alemã, Ayim foi deixada em um orfanato onde passou alguns meses antes de ser adotada por uma família alemã. Sua infância e adolescência - permeadas por experiências de racismo - são contadas por ela a partir dos anos 1980 em cartas, ensaios e poemas. Após terminar sua graduação em pedagogia e psicologia, Ayim muda-se para Berlim, cidade em que viveu desde 1984 até o dia de seu suicídio no ano de 1996. Nesta cidade, então, começa a participar do movimento de mulheres e logo publica alguns poemas no livro Farbe Bekennen: Afro-deutsche Frauen auf den Spuren ibrer Geschichte ${ }^{3}$, que reúne histórias de mulheres alemãs negras, publicado em 1986, mesmo ano da fundação da organização nacional de negros/as alemães Initiative Schwarze Deutscher (ISD) por May Ayim e outras ativistas negras. Este livro contém também o trabalho de conclusão de curso de Ayim, intitulado Afro-alemães: sua bistória cultural e social sob o plano de fundo da mudança social, primeiro trabalho acadêmico sobre a história de pessoas negras nascidas e residentes na Alemanha, que remonta à presença de negros/as neste território desde a Idade Média. A pesquisa desvela o passado colonial alemão - assunto negligenciado nos livros de história oficial - além de compreender a realidade de negros/as na Alemanha contemporânea ao lançamento do livro. No prefácio desta obra, as organizadoras - entre elas Ayim afirmam: "Com este livro queremos - juntamente a experiências pessoais - revelar contextos sociais racistas". E continuam: "Nossas vidas serão mais leves, quando não tivermos que explicar exausta e repetidamente nossa existência" (OGUNTOYE; OPITZ; SCHULTZ, 1986, p. 10).

No início dos anos 1990, Ayim viaja ao Caribe, Estados Unidos, Gana e África do Sul recitando sua poesia em festivais e eventos antirracistas. Em maio de 2010, a antiga rua Gröbenufer em Berlim, cujo nome homenageava Otto Friedrich von der Gröben (16571728), um colonizador alemão que liderou em 1683 uma expedição ao oeste africano, passou - depois da pressão da ISD - a homenagear a poeta, passando a se chamar "May Ayim-Ufer". Ayim foi também uma das primeiras poetas negras a escrever em língua

\footnotetext{
${ }^{3}$ Publicado em 1986 e em tradução livre: Mostrando CORagem: mulheres afro-alemãs em busca de suas histórias.

4 "Unsere Leben wird leichter sein, wenn wir nich mehr immer von neuem unsere Existenz erklären müssen”. Tradução minha.
} 
alemã, influenciando sua geração e gerações seguintes de afro-alemães e afro-austríacos. Audre Lorde, figura de extrema importância para o nascimento do movimento negro alemão afirma, no prefácio da tradução estadunidense do livro Farbe bekennen ${ }^{5}$ :

Este livro vem para nos lembrar, mulheres afro-estadunidenses, que nós não estamos sozinhas em nossa situação no mundo. Na atual conjuntura internacional, conexões vitais e diferenças existem e precisam ser examinadas entre mulheres afro-europeias, afro-asiáticas e afroamericanas, bem como entre nós e nossas irmãs africanas. Os primeiros passos para examinar tais conexões são identificar a nós mesmas, reconhecer-nos entre nós e escutar cuidadosamente nossas vozes (LORDE, 2009, p. 176, grifo meu).

A dissertação de mestrado intitulada "May Ayim e a tradução de poesia afrodiaspórica de língua alemã" é um estudo da obra lírica da afro-alemã e contém 12 poemas de sua autoria traduzidos para o português brasileiro e comentados. Esse projeto realizou-se como ato de escuta e ampliação da voz afrodescendente da poeta, mas também de voz da tradutora, também afrodescendente. Tatiana nascimento dos santos (2014, p. 31), refletindo sobre a importância da tradução de mulheres negras, chama a atenção para:

[...] as relações de poder [que] criam uma dinâmica de escuta e silenciamentos em que determinadas vozes são ouvidas ou hiperamplificadas, e outras são repetidamente ignoradas. O caso seria, então, precisamente o de rearticular a escuta, e não de "dar a voz" - [...] é importante justificar que esse silenciamento é profundamente simbólico e completamente relacionado, de onde vejo, a essas inescutas sistematizadas (SANTOS, 2014, p. 31).

Sobre "inescutas", Ayim escreve o poema Afro-deutsch I, transcrito e traduzido abaixo:

\section{Afro-deutsch I}

Sie sind afro-deutsch? ...

ah, ich verstehe: afrikanisch und deutsch. Ist ja ne interessante Mischung!

Wissen Sie, manche, die denken die Mulatten, die würden's nicht soweit bringen wie die Weißen

Ich glaube das nicht.

Ich meine, bei entsprechender Erziehung ...

Sie haben ja echt Glück, daß Sie

bier aufgewachsen sind

Bei deutschen Eltern sogar. Schau an!

\section{Afro-Alemã I}

Você é o que? Afro-Alemã? Ah! Entendi...: africana $e$ alemã

Não é que dá uma mistura interessante!

Sabe que muitos ainda pensam que mulatos não conseguem ir tão longe na vida como os brancos

Mas eu não acredito nisso.

Quer dizer: com a mesma educação...

Que sorte a sua ter crescido aqui.

Ainda mais com pais alemães. Veja só!

\footnotetext{
5 “This book serves to remind African-American women that we are not alone in our world situation. In the face of new international alignments, vital connections and differences exist that need to be examined between African-European, African-Asian, African-American women, as well as between us and our African sisters. The first steps in examining these connections are to identify ourselves, to recognize each other, and to listen carefully to each other's stories". Tradução minha.
} 
Wollen Sie denn mal zurück?

Wie, Sie waren noch nie in der Heimat vom Papa?

Das ist aber traurig... Also, wenn Sie mich fragen:

So 'ne Herkunft, das prägt eben doch ganz schön.

Ich zum Beispiel bin aus Westfalen und ich

finde

da gehör ich auch hin...

Ach Menschenskind, das ganze Elend der Welt!

Sei'n Se froh, daß Sie nicht im Busch geblieben sind.

Da wär'n Sie heute nich so weit!

Ich meine, Sie sind ja wirklich ein intelligentes Mädchen.

Wenn Sie fleißig sind mit Studieren

können Sie ja Ihren Leuten in Afrika helfen:

Dafür sind Sie doch prädestiniert, auf Sie

hör'n die doch bestimmt, während unsereins...

ist ja so'n Kulturgefälle...

Wie meinen Sie das? Hier was machen.

Was woll'n Sie denn hier schon machen?

Ok., ok., es ist nicht alles eitel Sonnenschein.

Aber ich finde, jeder sollte erstmal vor seiner eigenen Tür fegen.
Você não tem vontade de voltar algum dia, hein? $\mathrm{O}$ que? Você nunca esteve na terra do seu pai? Ai que triste... Olha, se você me perguntar: Uma origem dessa deixa uma marca e tanto. Eu, por exemplo, sou de Westphalia, $\therefore$ acho que lá é meu lugar...

Gente! Com toda miséria nesse mundo! Ainda bem que você não ficou na selva, pois hoje não estaria onde está!

Quer dizer, você é mesmo uma mocinha bem inteligente.

Se estudar bastante

Vai poder ajudar sua gente lá na África:

Você foi predestinada para isto! Eles te ouvirão com certeza,

Já a nós aqui -

Bem, há um desnível cultural tão grande...

O que você quer dizer? Fazer algo aqui.

Que diabos cê poderia fazer aqui, hein?

Ok, ok... nem tudo são flores,

Mas acho que, em primeiro lugar cada um tem que olhar pro seu próprio rabo!

(AYIM, 1995, p. 18-19)

Neste poema May Ayim, com ironia e agudez, reproduz um "diálogo" no qual uma espécie de "ignorância" misturada à "polidez" do sujeito branco discrimina esse eu-lírico afro-alemão fazendo-o lembrar que sempre será o "outro". O poema reproduz a dinâmica do discurso branco que parece falar sozinho, silenciando a voz negra. Entretanto, o que Ayim faz através do poema é demonstrar o quão racista o "senso comum" é, e faz isso demonstrando que conversas "inocentes" podem reproduzir muito racismo. Para isso, a poeta se utiliza de expressões corriqueiras da língua alemã, que carregam uma história de preconceito e reproduzem o racismo. Com isso, a poeta usa a língua alemã como uma ferramenta para reverter a subordinação, pois agora é, de fato, ela quem escreve.

Em última instância, é possível ler o poema na chave da ironia, já que as frases parecem ter sido decoradas pelo eu-lírico, exprimindo as inúmeras vezes que ele já foi obrigado a ouvi-las, enunciadas tão trivialmente por sujeitos brancos. Tais "diálogos", na verdade, dizem ao sujeito negro: "o que você faz aqui?", "Quando você vai embora?", "Não se intrometa nos assuntos do meu país", "Eu não sou racista", "Eu não preciso mudar", "Você vê racismo em tudo", etc. O que está implícito nessa dinâmica é o poder da supremacia branca de determinar o que é racismo ou não. A escritora e artista interdisciplinar Grada Kilomba (2010) elucida a questão: 
[...] o racismo é possibilitado por meio de uma definição de poder, isto é, aqueles/as que praticam o racismo não têm somente a crença de que o que fazem está correto, mas também o privilégio e o poder de definir se determinados termos são racistas ou difamatórios frente àqueles/as que são discriminados/as (através destes termos). Esta é uma situação absurda, pois tanto as perspectivas, quanto as definições e o conhecimento daqueles/as que experienciam o racismo tornam-se completamente irrelevantes. Neste jogo não há compaixão, tampouco simpatia ou responsabilidade, uma vez que a pessoa que usa tais termos não tem nenhum interesse no que o racismo pode desencadear. O que interessa tal pessoa é a "liberdade" de poder continuar exercendo o racismo. Tal desejo é tão grande que ele ou ela ousa argumentar que aquilo que é, de fato, racista, não tem o intuito de sê-lo. Um narcisismo denso e inabalável ou "um estado maníaco" como Frantz Fanon descreveu de forma tão bela em seu livro Pele Negra Máscaras Brancas ${ }^{6}$ (KILOMBA, 2010, p. 69).

O poema Afro-Alemã I pode ser lido como gênese do movimento negro alemão iniciado nos anos 1980 que buscava então a autodefinição e a formação de um sujeito político, antes somente denominado por meio de palavras racistas. Enxergo nesse ato uma intensa convergência como o pensamento amefricano ${ }^{7}$ de Lélia Gonzalez, que abre caminhos para pensarmos além do modelo binário colonial. Segundo Cardoso (2014), através da Amefricanidade, Gonzalez:

critica a ciência moderna como padrão exclusivo para a produção do conhecimento, vê a hierarquização de saberes como produto da classificação racial da população, uma vez que o modelo valorizado e universal é branco. Disto decorre que a explicação epistemológica eurocêntrica conferiu ao pensamento moderno ocidental a exclusividade do conhecimento válido, estruturando-o como dominante [...] (CARDOSO, 2014, p. 971).

Assim, na confluência do pensamento de Gonzalez penso que tanto a "afroalemanidade" ou "alemafricanidade" de May Ayim podem ser apreendidas em sua obra, seja pelos temas tratados, quanto pelos modos; um exemplo de como ela logra articular sua identidade é através da junção da língua alemã com símbolos adinkra, que compõem seu livro de poemas "Blues em Preto e Branco", de 1995 e ainda sem tradução para o português. A identidade afro-alemã ultrapassa fronteiras nacionais "incorporando todo um processo histórico" da presença de negros/as em um território que os/as apaga e silencia e afastando

\footnotetext{
6 "Es ist ein gutes Beispiel wie Rassismus durch eine Machtdefinition bewilligt wird, das heißt die, die Rassismus praktizieren, haben nicht nur den Glauben an das Richtige ihrer Sache, sondern auch das Privileg und die Macht zu definieren, ob bestimmte Begriffe rassistisch oder diffamierend gegenüber denen sind, die diskriminiert werden. Eine absurde Situation, da die Perspektiven, die Definitionen und das Wissen von denen, die Rassismus erleben, absolut irrelevant wird. In diesem Spiel gibt es weder Mitgefühl noch Sympathie oder Verantwortung, da die Person, die diesen Brief schreibt, kein Interesse daran hat, was Rassismus auslösen kann. Was ihn oder sie interessiert, ist die ,Freiheit ${ }^{\star}$ Rassismus weiter ausüben zu dürfen. Dieser Wunsch ist so groß, dass man sich zu argumentieren traut, dass das, was als rassistisch bezeichnet wird, nicht die Absicht hat, rassistisch zu sein. Ein massiver Narzissmus oder wie es Frantz Fanon so schön in seinem Buch, Black Skin, White Masks beschreibt, ein manischer Status". Tradução minha.

7 "As implicações políticas e culturais da categoria de Amefricanidade [Amefricanity] são, de fato, democráticas; exatamente porque o próprio termo nos permite ultrapassar as limitações de caráter territorial, linguístico e ideológico, abrindo novas perspectivas para um entendimento mais profundo dessa parte do mundo onde ela se manifesta: A AMÉRICA [...]. Para além do seu caráter puramente geográfico, a categoria de Amefricanidade incorpora todo um processo histórico de intensa dinâmica cultural (adaptação, resistência, reinterpretação e criação de novas formas) que é afrocentrada [...]” (GONZALEZ, 1988, p. 76-77).
} 
o perigo da história única ${ }^{8}$ (ADICHIE, 2009). Gonçalves também, nesse sentido, em Um defeito de cor, reescreve a história de nossas/os antepassadas/os contra o perigo da história única, como já demonstrado. O escritor afro-brasileiro Machado de Assis no conto Pai contra Mãe, publicado em 1906, escreve:

A escravidão levou consigo ofícios e aparelhos, como terá sucedido a outras instituições sociais. (...) Um deles era o ferro ao pescoço, outro o ferro ao pé; havia também a máscara de Flandres. A máscara fazia perder o vício da embriaguez aos escravos, por lhes tapar a boca. Tinha só três buracos, dous para ver, um para respirar, e era fechada atrás da cabeça por um cadeado. (...) Era grotesca tal máscara, mas a ordem social e humana nem sempre se alcança sem o grotesco, e alguma vez o cruel. Os funileiros as tinham penduradas, à venda, na porta das lojas (...) O ferro ao pescoço era aplicado aos escravos fujões. Imaginai uma coleira grossa, com a haste grossa também, à direita ou à esquerda, até ao alto da cabeça e fechada atrás com chave (ASSIS, 1986, p. 28).

Grada Kilomba, escritora e artista interdisciplinar afro-portuguesa inicia seu livro Plantation memories: episodes of everyday racism com a imagem da escravizada Anastácia e da máscara de Flandres, que chama de "máscara do silenciamento" (KILOMBA, 2016, p. 171):

(...) a máscara representa o colonialismo como um todo. Ela simboliza políticas sádicas de conquista e dominação e seus regimes brutais de silenciamento dos(as) chamados(as) 'Outros(as)': Quem pode falar? O que acontece quando falamos? E sobre o que podemos falar? (KILOMBA, 2016, p. 172).

Em Um defeito de cor há diversas passagens ao longo da vida de Kehinde nas quais ela é castigada pela sinhá Ana Felipa, ou reprimida por Esméria por (querer) falar. O impedimento de dizer o que pensa e o que quer a acompanha por toda vida como algo ligado à sua condição de negra escravizada, e mesmo depois de comprar sua liberdade Kehinde/Luisa, muitas vezes não pode dizer o que pensa. Contudo, ao final da vida, a narradora articula a fala e conta sua história com muitos detalhes, incluindo em sua narrativa o que pensara em diversas passagens nas quais se mantivera calada. Já idosa e rica confessa:

Eu achava que era só no Brasil que os pretos tinham que pedir licença do defeito de cor para serem padres, mas vi que não, que na África também era assim. Aliás, em África, defeituosos deviam ser os brancos, já que aquela era a nossa terra e éramos em maior número. O que pensei naquela hora, mas não disse, foi que me sentia muito mais gente, muito mais perfeita e vencedora que o padre. Não tenho defeito algum e, talvez para mim, ser preta foi e é uma grande qualidade, pois se fosse branca não teria me esforçado tanto para provar do que sou capaz, a vida não

\footnotetext{
${ }^{8}$ Faço referência ao discurso da escritora nigeriana Chimamanda Adichie intitulado "O perigo da história única", no qual Adichie discorre sobre nossa vulnerabilidade diante uma versão da história, que quando contada muitas vezes, passa a ser a única versão, passa a ser a verdade. A escritora aponta para os efeitos nocivos desta história única e diz que a descoberta de autores/as africanos/as a salvou de conhecer somente uma versão da história, versão esta que a excluía e a fazia viver em um mundo que não correspondia ao que conhecia.
} 
teria exigido tanto esforço e recompensado com tanto êxito (GONÇALVES, 2006, p. 893, grifo meu).

É importante ressaltar que, apesar dos silenciamentos na vida de Kehinde/Luisa, em diversos momentos, nos quais conseguira articular sua fala e ser ouvida, ela obtém exito. Como na passagem em que, como escravizada de ganho, oferece seus cookies para uma loja de iguarias:

De início tentaram me enxotar enquanto eu dava uma olhada nas prateleiras, dizendo que os produtos que estavam ali não eram para o meu paladar e muito menos para o meu bolso. Mas eu disse que tinha ido a mando da minha sinhá e perguntei se eles vendiam English cookies, caprichando na pronúncia. [...] Eu então falei que nós, e salientei o "nós" para que ele pensasse que havia mesmo alguma sinhá por trás daquela minha atitude, que nós na verdade não estávamos procurando cookies para comprar, mas sim quem aceitasse vendê-los. Completei dizendo que pertencia a uma senhora que, if you do not mind, preferia permanecer anônima, tinha herdado uma receita de legítimos cookies ingleses e, por causa de problemas que não vinham ao caso, if you understand, pensava em fazer de tais iguarias uma fonte de renda. Falei assim mesmo, emendando frases em inglês para impressionar, e deu certo. $\mathrm{O}$ encarregado me olhava espantado, tentando esconder que não sabia falar inglês, deixando-me muito feliz por estar agradando, o que já resolvia parte do problema: ser owvida (GONÇALVES, 2006, p. 273-274, grifo meu).

Este trecho é alegórico e demonstra a capacidade e o poder da fala, que uma vez, permitida a negras/os pode significar êxito e liberdade. Kehinde pretendia com a venda dos cookies comprar sua alforria, bem como a de seu filho e para isso não poupou esforços, utilizando seus conhecimentos da língua inglesa para impressionar e convencer o funcionário da loja. Não se pode deixar de notar o momento em que Kehinde diz que "ser ouvida" já resolvia parte do (seu) problema, já que enquanto negra escravizada nunca tivera tal privilégio. Nesta cena, Kehinde consegue inverter uma dinâmica racial que estabelece que negras/os não são capazes de falar (uma segunda língua), tampouco de fazer uma iguaria como os English cookies. Neste trecho então, fica expresso que a articulação da escuta alheia é imprescindível para a vida de Kehinde, o que nos revela também mais uma faceta cruel do racismo, isto é, em um mundo escravocrata patriarcal da supremacia branca, mesmo que nós negras e negros falemos, são raras as vezes que não precisamos de uma pessoa branca para legitimar nossa voz. O processo de erradicação do racismo passa, imprescindivelmente, pela fala do sujeito subalternizado impedido de falar, inadiavelmente pela escuta desta voz, e sobretudo, pela supressão da dinâmica racista que autoriza uma voz branca legitimadora da vOz negra.

Tanto Ayim quanto Gonçalves, duas afrodescendentes, com suas obras literárias articulam suas vozes e as usam desde continentes diferentes, em línguas e épocas distintas, para contarem histórias que mais parecem segredos como a escravidão, como o colonialismo e como o racismo.

Por isso também é impossível aproximar-se da obra lírica de Ayim somente através da perspectiva da literatura ou cultura alemã, pois sua poesia extrapola tais espectros. Esta prática de romper silenciamentos estaria em confluência com a escrita chicana de Gloria Anzaldúa, entre outras, que segundo Cardoso (2014, p. 966) "vêm atuando como forasteiras de dentro (outsiders within), reinventando definições, delimitando lugares sociais 
para melhor se posicionarem, como forma de realizarem a autodefinição", bem como com o pensamento/escrita de Lélia Gonzalez que, salvo diferenças de contexto e língua "confronta o padrão dominante [...] enreda[ndo] o português com elementos linguísticos africanos, em uma tentativa política de evidenciar o preconceito racial existente na própria definição da língua materna brasileira" (CARDOSO, 2014, p. 966-967). Também Ayim, segundo Chris Köver (2014), "[...] transforma em poesia os resíduos de palavras racistas da sociedade alemã". Assim, o projeto literário da poeta produz um movimento de apropriação da língua hegemônica e racista. Traduzi-la então configura-se como um contínuo da prática de romper o silenciamento racista colonial em nome de nossa ancestralidade "como ética e como encantamento", que segundo Oliveira (2012, p. 16) "nos mobiliza para a conquista, manutenção e ampliação da liberdade de todos[as] e de cada um[a] [...]. Uma atitude que faz sentido, se confrontada com o legado de nossos antepassados". Deste modo, compartilho com minha tradução de Ayim, como fez e faz a poeta e escritora afro-brasileira Conceição Evaristo, as "vozes-mulheres" em diásporas ou "vozes do mundo", pois como também apontara o martinicano "existe muito prazer em compartilhar tais vozes".

Ressalto a agência negra nos campos das Artes e Literatura como campos de enunciação, potência e afrontamento nas mais diversas nações e línguas nacionais, contra silenciamentos e inescutas seculares e como estratégia anti-colonial, recontando histórias e transformando o ponto de vista hegemônico acerca da produção cultural, da articulação de discursos e da história. Destaco a produção de narrativas afrodescendentes em alemão e seu potencial desmantelador de narrativas universais de nação e de literaturas nacionais. Reconhecer essa literatura negra alemã é então borrar a narrativa nacional e legitimar a existência negra diáspora nesse território, é criar laços transatlânticos e transnacionais negros, tecendo a colcha de retalhos de nossas memórias, de nossos corpos nos diálogos (im)possíveis e redes ancestrais entre a produção artístico-cultural afro-europeia e afrolatinoamericana. Tais produções culturais contribuem para o processo de re-oritologização ${ }^{10}$ dos povos negros. Tal processo se refere ao resgate, aproximação, reconhecimentos e partilhas não apenas de memórias, mas trata-se de um resgate cognitivo e ontológico de negros em diáspora.

\section{Referências}

ADICHIE, Chimamanda. O perigo da história única, 2009. Disponível em: https://www.youtube.com/watch?v=wQk17RPuhW8. Acesso em: 19 out. 2018.

ASSIS, Machado. Pai contra Mãe. In: ASSIS, Machado. Os melhores contos: 6. Seleção de Domício Proença Filho. 3 ed. São Paulo: Global, 1986.

AYIM, May. Blues in Schwarz Weiss: Gedichte. Berlim: Orlanda Frauenverlag, 1995.

\footnotetext{
9 "Edouard Glissant parle de tolérance". Disponível em https://www.youtube.com/watch?v=AqH6sqrC_Hs. Acesso em: 19 out. 2018.

10 Termo elaborado durante encontros da Escola Ubuntu de Filosofia e Teologia Afrocentrada/Decolonial e do Fórum Ubuntu Afro-Brasileiro na cidade de Florianópolis 2107 e 2018, onde participavam Jayro Pereira de Jesus, Luck Palhano, Cauane Maia, Elisangela de Paula Palhano, entre outros/as intelectuais.
} 
CARDOSO, Claudia Pons. Amefricanizando o feminismo: o pensamento de Lélia Gonzalez. Revista Estudos Feministas, Florianópolis, v. 22, n. 3, p. 965-986, set./dez. 2014.

CUTI. Literatura negro-brasileira. São Paulo: Selo Negro, 2010.

DUARTE, Eduardo de Assis. Na cartografia do romance afro-brasileiro: Um defeito de cor, de Ana Maria Gonçalves, 2011. Disponível em: http://www.letras.ufmg.br/literafro/autoras/29-critica-de-autores-feminios/442-nacartografia-do-romance-afro-brasileiro-um-defeito-de-cor-de-ana-maria-goncalves. Acesso em: 19 out. 2018.

EVARISTO, Conceição. Conceição Evaristo: "Nossa fala estilhaça a máscara do silêncio" [13/05/2017]. Entrevista concedida a Djamila Ribeiro. Disponível em: https://www.cartacapital.com.br/sociedade/conceicao-evaristo-201 cnossa-fala-estilhaca-amascara-do-silencio201d. Acesso em: 19 out. 2018.

GONÇALVES, Ana Maria. Um defeito de cor. 6. ed. Rio de Janeiro: Record, 2010.

GONÇALVES, Ana Maria. The Intercept Brasil apresenta Ana Maria Gonçalves, nova colunista de assuntos raciais, culturais e políticos [2016]. Disponível em: https://theintercept.com/2016/12/02/the-intercept-brasil-apresenta-ana-maria-goncalvesnova-colunista-de-assuntos-etnicos-raciais-e-politicos/. Acesso em: 19 out. 2018.

GONZALEZ, Lélia. A categoria político-cultural de amefricanidade. Tempo Brasileiro, Rio de Janeiro, n. 92/93, p. 69-82, jan./jun. 1988.

HUTCHEON, Linda. Poética do pós-modernismo. Rio de Janeiro: Imago, 1991.

JUNIOR, Marcelo Cruz Dalcom. Nas entrelinhas de Um defeito de cor: desvio, discursos históricos e literários. Anais do Congresso Internacional da ABECAN, 11. Disponível em: http://www.anaisabecan2011.ufba.br/Arquivos/Dalcom-Souza.pdf. Acesso em: 19 out. 2018.

KILOMBA, Grada. "Unerzählte Teile der Geschichte" (Entrevista). Hinterland, n. 15, p. 68-71, out./dez. 2010. Disponível em: http://d-nb.info/1011674246/34. Acesso em: 19 out. 2018.

KILOMBA, Grada. A Máscara. Tradução: Jessica Oliveira de Jesus. Cadernos de Literatura em Tradução, n. 16, p. 171-180, maio 2016. Disponível em:

http://www.revistas.usp.br/clt/article/view/115286. Acesso em: 19 out. 2018.

KÖVER, Chris. Unverschämt schwarz. Missy Magazine. Disponível em: http://missymagazine.de/2014/05/02/unverschamt-schwarz/. Acesso em: 19 out. 2018.

LORDE, Audre. Foreword to the English edition of Farbe Bekennen: afro-deutsche frauen auf den spuren ihrer geschichte. In: BYRD, Rudolph P.; COLE, Johnnetta Betsch; GUYSHEFTALL, Beverly (org.). I am your sister: collected and unpublished writings of Audre Lorde. Nova Iorque: Oxford University Press, 2009. 
MENNUCCI, Sud. O precursor do abolicionismo no Brasil (Luiz Gama). São Paulo: Companhia Editora nacional, 1938.

OGUNTOYE, Katharina; OPITZ, May; SCHULTZ, Dagmar. Vorwort der Herausgeberinnen. In: OGUNTOYE, Katharina; OPITZ, May; SCHULTZ, Dagmar (org.). Farbe bekennen: afro-deutsche frauen auf den spuren ihrer geschichte. Berlim: Orlanda Frauenverlag, 1986.

OLIVEIRA, Eduardo David de. Filosofia da ancestralidade como filosofia africana: educação e cultura afro-brasileira. Revista Sul-Americana de Filosofia e Educação, Brasília, n. 18, p. 28-47, maio/out. 2012.

SANTOS, tatiana nascimento dos. Letramento e tradução no espelho de Oxum: teoria lésbica negra em auto/re/conhecimentos. 2014. Tese (Doutorado em Estudos da Tradução) - Universidade Federal de Santa Catarina, Florianópolis, 2014.

WEINHARDT, Marilene. Um defeito de cor e muitas virtudes narrativas. Revista Letras, Curitiba, n. 77, p. 107-123, jan./abr. 2009. 